UDC 336.13:331.522.4

JEL Classification: C54, E24, E60, G28

http://doi.org/10.21272/mmi.2018.4-17

Liudmyla Kozarezenko,

D.Sc., Professor, Kyiv National University of Trade and Economics, Ukraine

Yuriy Petrushenko,

D.Sc., Professor, Sumy State University, Ukraine

Oksana Tulai,

D.Sc., Professor, Ternopil National Economic University, Ukraine

\title{
INNOVATION IN PUBLIC FINANCE MANAGEMENT OF SUSTAINABLE HUMAN DEVELOPMENT
}

Abstract. It is proved that peculiarities of countries with the social-oriented economy are defined by either sufficient costs for the social sphere maintenance and development, or also by their essential influence on the citizens welfare, as evidenced by the human development index, which is calculated on the basis of the citizens' material situation indicators and social and demographic indicators. Countries with Scandinavian and Western European social and economic development models are in the category with the highest level of human development. It has been revealed that although the state provides great financial support for the social sphere in these countries, financing sources diversification of projects and programs in the educational and medical branches is growing, the insurance medicine and accumulative level of the pension system are being developed. In general, innovative approaches to the financing of social programs are often used. The reasonability to use the integral system of the economy financial control, further improvement of assumptions regarding institutional mechanisms to provide sustainable human development, which are purposefully used by state institutions, is proved. The proposed model and calculations help to prove marginal conditions of the social costs' regulation of the State and local budgets of Ukraine, oriented to the human development. It is justified, that $10 \%$ is an optimal marginal norm of the annual rates regarding the relevant costs growth over the five years. Therefore, the annual decrease of the financing amounts over $10 \%$ of the financing amounts from the previous years are not accepted. It is emphasized that the financial management system of the sustainable human development has to be improved taking into account the public development priorities, economic cyclicity, the financial system transformations and the leading experience of the countries with the developed and transformational economy, in the first place in the application of innovative financial instruments of human development.

Keywords: financial policy, budget policy, financial provision, budget costs, innovations, sustainable human development.

Introduction. Under conditions of the world economic unstable development, the problem to activate the role of the state fiscal policy role regarding the formation of the favourable conditions for human development and renewal of the positive economic dynamics become important. The competitive economy, production improvement and institutional environment form the background to provide long-term economic growth. Dynamic transformations of the country's economic model require the use of not only a balanced but also an innovative approach to determine rational methods of financial regulation in relation to sectors of social production.

The financial constituent of the human development has to provide stage-by-stage raising of the level and quality of life, to assist improvement of the institutional structure in the social sphere, increase of labour productivity, increase of the science-intensive and high-tech products share in the gross domestic product. It is important to implement the systematic and balanced state policy in the sphere of financial support for human development, using the budget, tax, credit and insurance instruments. It is reasonable to improve the institutional bases financial regulation of human development, including education, science, health protection, the social sphere and labour market.

Cite as: Kozarezenko, L., Petrushenko, Y., \& Tulai, O. (2018). Innovation in Public Finance Management of Sustainable Human Development. Marketing and Management of Innovations, 4, 191-202. http://doi.org/10.21272/mmi.2018.4-17 
Analysis of recent studies and publications. The great contribution to the evolution of the theoretical and practical aspects to form the financial regulation system of human development has been made by such foreign scientists and experts as Y. Campbell (Campbell, 2006), N. Hicks (Hicks, 1980), R. Lucas (Lucas, 1988), F. Machlup (Machlup, 1984), G. Mankiw, D. Romer, D. Weil (Mankiw, Romer, Weil, 1992), S. Mehrotra (Mehrotra, 1997), K. Murphy, A. Shleifer, R. Vishny (Murphy, Shleifer, Vishny, 1991), who studied the efficiency of costs influence at the state and private levels on the human capital constituents, and V. Popov (Popov, 2011), A. Sen (Sen, 1989), D. Wheeler (Wheeler, 1980), J. Stiglitz (Stiglitz, 2011), V. Kolesov (Kolesov, 2008), who studied dependence of the social and economic development rates and financial regulation and financial provision efficiency of education, health protection and other spheres in the national economy.

The problem regarding the financial provision of human development, improvement of the methodological principles regarding the state regulation system of human development is observed in works of the native scientists: I. Chugunov (Chugunov, Kozarezenko, 2017), O. Stefanishin (Stefanishin, 2006), I. Bobukh (Bobukh, 2014), T. Bogolib (Bogolib, 2015), L. Tarangul (Tarangul, 2012), V. Geets (Geets, 2009), T. Pospelova (Pospelova, 2011). The works of T. Bogolib, O. Stefanishin, I. Bobukh, T. Poselova presents the study of the financial regulation of some constituents in human development, particularly, education, health protection etc. The scientific studies of I. Chugunov, L. Tarangul evaluate the impact of financial provision and financial regulation mechanism on the human development process. Besides, the above works of foreign and native researchers do not have the integral representation of the effective financial regulation of human development, first of all, in conditions of the social and economic environment in Ukraine. Determination of the unsolved issues, which make the part of the general problem, which the article deals with. Under conditions of the economic transformations, it is important to find an adequate relevance regarding the state fiscal policy of human development. It indicates the urgency of the article and predetermined its aim and tasks.

Representation of the main results and their objectivation. Human development depends on the state of its dynamic features, including in the sphere of health protection, education and science, culture, inhabitants' incomes and their equality. The increased efficiency of the human development financial regulation is caused by the dynamics of the social changes and requires costs to finance social sphere and its infrastructure improvement differentiation of approaches to the social infrastructure financial provision, including in the part of state and market methods and forms combination, caused by peculiarities of the country's development economic model. The state financial policy should be oriented to create basic institutional preconditions to increase the human development level, its implementation possibilities.

Based on the study of the theoretical principles regarding the state financial regulation of human development (Tulai, 2016, Kozarezenko, 2016, Petrushenko, 2014, Chugunov, \& Kozarezenko, 2017). Its essence as a public development constituent is revealed. It provides to use the financial architectonics norms, rules, methods, forms, mechanisms, tools and levers in order to improve the institutional environment quality of the economic growth model and to improve the human development level in the conditions of integrational processes impact on the macroeconomic dynamics that will assist increasing the structural transformations efficiency in the economic and social sphere. The necessary prerequisites to ensure the intensive economic growth is an appropriate degree to develop educational and scientific potential, technological structures of economy, institutions and macroeconomic stability.

The state regulation experience regarding the human development of the highly-developed countries proves the increased funding of the educational and health protection spheres from the budget. The financing structure of branches, which influence human development in developed countries, significantly differs depending on the peculiarities of the social and economic systems.

In most developed countries the costs of the private sector are dominated in the financing structure of education and health protection. At the same time, countries with "Scandinavian" model of the economic 
development direct a significant share of the budget funds to finance activities regarding human development rates growth. In general, the average share of the public expenditure in the countries' gross domestic product during $2006-2016$ on health protection is $7.0 \%$, education $-5.1 \%$, social protection and social support - $18.7 \%$ in the EU Member States. According to the absolute indicators of human development financing, first of all, according to expenditure on education, health protection, social protection and social support per capita, Ukraine has a considerable gap with European countries.

The global experience justifies that the priority directions of the financial policy in the sphere of ensuring conditions for social development include the reduction of irregularity in the citizens' incomes distribution, improvement of the public services quality and accessibility, improvement of the criteria system to obtain the social assistance. Taking into account that fact that the demographic conjuncture is worsening, the significant trend is the increase of expenditure on the pension maintenance under conditions of the economic transformations.

The above changes cause the implementation of the consequent measures program regarding the retirement-age increase and encouragement of the later retirement, changes of pension accounting terms, the pension insurance record extension, which is necessary to receive a pension, change of the pension's indexation order. Today, there are no reasons to suppose that in the near future, our state can continue to redistribute state resources for social expenditure increase. Their unconsidered growth will not assist in solving the sustainable human development tasks but will lead to the budget crisis aggravation and economic perspectives loss. In view of this, the budget process should be shifted from the "resources management" to "results control".

The latter considers the formation of a budget, based on the aims and planned results. First of all, while planning the social expenditure from the budget, it is necessary to pay special attention to the results justification.

We suppose that efficiency in the social costs of the budget, oriented to human development, shows how far their distribution brings about the desired social effect. As a result of the sustainable human development promotion, the social effect includes the analysis regarding the influence of the social costs from state and local budgets on the citizens' life quality. The citizens' life quality is proposed to define by 15 criteria features:

- the average size of the household, persons (ASH);

- the share of households with children up to 18 years old, \% (SHC18);

- the share of households without children, \% (SHWC);

- the household expenses for food products (foodstuff and soft drinks)), \% (HEFP);

- the household expenses for non-food products and service, \% (HENP);

- the household expenses to pay for accommodation, communal products and service, $\%$ (HEACPS);

- unemployed persons aged 15-70 (by the methodology of ILO), in \% to the economically active population of the relevant age group (UP15-70);

- unemployed persons of the working age (by the methodology of ILO), thousand persons, in $\%$ to the economically active population of the relevant age group (UPWA);

- the coefficient of the workers' total turnover (CTWT);

- the total area of the housing stock, $m \ln ^{2}$ (TA);

- specific weight of the total area of housing stock, equipped with water supply, \% (SWTA);

- specific weight of the total area of housing stock, equipped with hot water supply, \% (SWTAHWS);

- the consumer price index in the health protection sector (CPIHP);

- the consumer price index in education (CPIE);

- the consumer price index in the recreation and culture field (CPIRC). 
In order to define the social effect, there is an "input-output" model, which describes the state funds functioning in the sustainable human development coordinates (figure 1).

There are priorities of the state's budget policy in the human development sector and resources for its fulfilment at «input» of the system, and at the «output» - real social effects as a consequence of the implemented decisions and goals achievement to improve the quality of people's life.

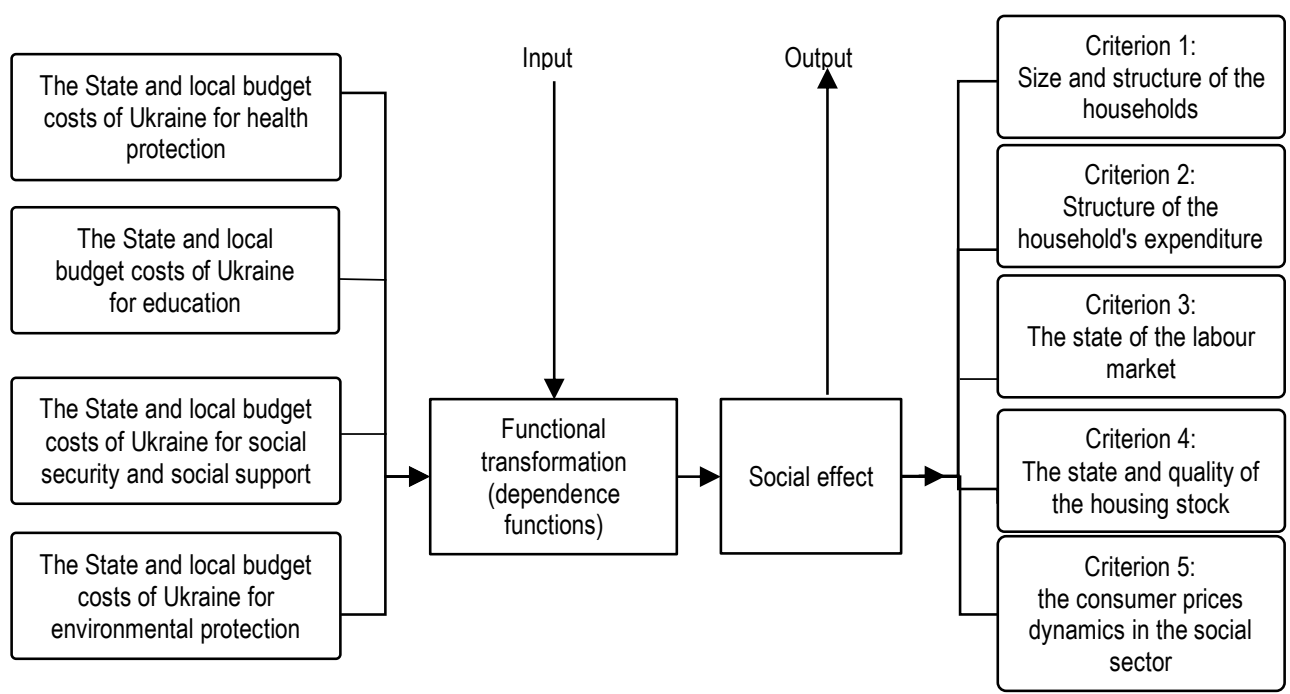

Figure 1 - Model «input-output» to evaluate the impact of social expenditure from the budget on the people's quality of life

Sources: constructed by authors

The instrument DataMining («STATISTICA 10») helps to establish the empiric dependence functions (the block of functional transformations of the proposed model) for the resultant criteria (size and structure of the households; households expenditure; the state of the labour market and quality of the housing stock; the consumer prices dynamics in the social sector, on the expenditure of the Ukrainian State and local budgets, oriented to human development, particularly:

- the State budget costs of Ukraine for health protection, mIn. UAH (CHCsb);

- the local budgets costs of Ukraine for health protection, mIn. UAH (CHClb);

- the State budget costs of Ukraine for education, mIn. UAH (CEsb);

- the local budgets costs of Ukraine for education, mIn. UAH (CEIb);

- the State budget costs of Ukraine for social protection and social support, mIn. UAH (CSPSSsb);

- the local budgets costs of Ukraine for social protection and social support, mIn. UAH (CSPSSIb);

- the State budget costs of Ukraine for environmental protection, mIn. UAH (CEPsb);

- the local budgets costs of Ukraine for environmental protection, mln. UAH (CEPIb).

It enables to imitate the predicted scenarios regarding the impact of social expenditure of the State and local budgets of Ukraine on the citizens' life quality results. Thanks to the computer modelling we receive the spline empirical dependence functions (table 1).

Based on the received functional representation of the model, the scenario modelling impact (increase or decrease) of social expenditure on the results of the citizens' life quality by the proposed criteria 
Table 1 - Dependence functions of the model to evaluate the social expenditure efficiency of the State and local budgets of Ukraine

\begin{tabular}{|c|c|}
\hline № & Empirical dependence function \\
\hline 1 & $\mathrm{ASH}=2.65+4.736 \mathrm{e}-005^{*} \max (0 ; \mathrm{CSPSSIb}-5)-2.32 \mathrm{e}-002^{*} \max (0 ; \mathrm{CEPsb}-0.5)$ \\
\hline 2 & SHC18 $=39.2+0.016^{*} \max (0 ;$ CSPSSIb -5$)-0.792^{*} \max (0 ;$ CEPsb -0.5$)$ \\
\hline 3 & SHWC $=60.82-0.017^{*} \max (0 ;$ CSPSSIb -5$)+0.72^{*} \max (0 ;$ CEPsb -0.5$)$ \\
\hline 4 & HEFP $=57.42+0.05279^{*} \max (0 ;$ CSPSSIb -5$)-3.05^{*} \max (0 ;$ CEPsb -0.5$)$ \\
\hline 5 & HENP $=31.79+0.0658^{*} \max (0 ;$ CSPSSIb -5$)+1.504^{*} \max (0 ;$ CEPsb -0.5$)$ \\
\hline 6 & HEACPS $=8.077+0.0371^{*} \max (0 ;$ CSPSSIb -5$)-0.481^{*} \max (0 ;$ CEPsb -0.5$)$ \\
\hline 7 & UP15-70 = $8.84+0.0628^{*} \max (0 ;$ CSPSSIb -5$)-1.2741^{*} \max (0 ;$ CEPsb -0.5$)$ \\
\hline 8 & UPWA $=9.4875+0.07^{*} \max (0 ;$ CSPSSIb -5$)-1.337^{*} \max (0 ;$ CEPsb -0.5$)$ \\
\hline 9 & CTWT $=53.82-0.222^{*} \max (0 ;$ CSPSSIb -5$)+4.11^{*} \max (0 ;$ CEPsb - 0.5) \\
\hline 10 & $\mathrm{TA}=1034.02-3.22540^{*} \max (0 ;$ CSPSSIb -5$)+53.727^{*} \max (0 ; \mathrm{CEPsb}-0.5)$ \\
\hline 11 & SWTA $=55.000+0.003^{*} \max (0 ;$ CSPSSIb -5$)+1.422240 \max (0 ;$ CEPsb -0.5$)$ \\
\hline 12 & SWTAHWS $=39.09406+0.112^{*} \max (0 ;$ CSPSSIb -5$)+0.255^{*} \max (0 ;$ CEPsb -0.5$)$ \\
\hline 13 & $\mathrm{CPIHP}=109.149+0.60^{*} \max (0 ; \mathrm{CSPSSIb}-5)-6.935^{*} \max (0 ; \mathrm{CEPsb}-0.5)$ \\
\hline 14 & CPIE $=112.72+0.0013^{*} \max (0 ;$ CSPSSIb -5$)-0.72^{*} \max (0 ;$ CEPsb -0.5$)$ \\
\hline 15 & CPIRC $=104.28+0.67^{*} \max (0 ;$ CSPSSIb -5$)-7.239^{*} \max (0 ;$ CEPsb -5$)$ \\
\hline
\end{tabular}

Sources: it is calculated by authors.

Table 2 shows the results of the predicted values of the impact regarding the State and local budgets social expenditure growth on the citizens' life quality by three scenarios.

Table 2 - Predicted impact of the social expenditure growth of the State and local budgets of Ukraine on the citizens' life quality

\begin{tabular}{|c|c|c|c|c|c|c|c|}
\hline & Indicators of citizens' life quality & $\begin{array}{l}\text { Rates of } \\
\text { the } \\
\text { expendit } \\
\text { ure } \\
\text { growth }\end{array}$ & 2016 & 2017 & 2018 & 2019 & 2020 \\
\hline 1 & 2 & 3 & 4 & 5 & 6 & 7 & 8 \\
\hline \multirow{3}{*}{1} & \multirow{3}{*}{$\begin{array}{l}\text { The average size of the household, } \\
\text { persons }\end{array}$} & $5 \%$ & 2.57 & 2.56 & 2.56 & 2.55 & 2.53 \\
\hline & & $10 \%$ & 2.56 & 2.55 & 2.54 & 2.53 & 2.52 \\
\hline & & $20 \%$ & 2.56 & 2.55 & 2.54 & 2.53 & 2.52 \\
\hline \multirow{3}{*}{2} & \multirow{3}{*}{$\begin{array}{l}\text { The share of households with children } \\
\text { up to } 18 \text { years old, } \%\end{array}$} & $5 \%$ & 37.63 & 37.45 & 37.25 & 37.03 & 36.79 \\
\hline & & $10 \%$ & 37.72 & 37.63 & 37.54 & 37.44 & 37.34 \\
\hline & & $20 \%$ & 37.72 & 37.63 & 37.54 & 37.44 & 37.34 \\
\hline \multirow{3}{*}{3} & \multirow{3}{*}{$\begin{array}{l}\text { The share of households without } \\
\text { children, } \%\end{array}$} & $5 \%$ & 62.37 & 62.55 & 62.75 & 62.97 & 63.21 \\
\hline & & $10 \%$ & 62.28 & 62.37 & 62.46 & 62.56 & 62.66 \\
\hline & & $20 \%$ & 62.28 & 62.37 & 62.46 & 62.56 & 62.66 \\
\hline \multirow{3}{*}{4} & \multirow{3}{*}{$\begin{array}{l}\text { The household expenses for food } \\
\text { products (foodstuff and soft drinks)), } \%\end{array}$} & $5 \%$ & 49.9 & 49.46 & 49 & 48.51 & 48 \\
\hline & & $10 \%$ & 49.48 & 48.56 & 47.55 & 46.43 & 45.21 \\
\hline & & $20 \%$ & 49.9 & 49.46 & 49 & 48.51 & 48 \\
\hline \multirow{3}{*}{5} & \multirow{3}{*}{$\begin{array}{l}\text { The household expenses for non-food } \\
\text { products and service, } \%\end{array}$} & $5 \%$ & 37.83 & 38.17 & 38.53 & 38.9 & 39.3 \\
\hline & & $10 \%$ & 38.15 & 38.87 & 39.65 & 40.52 & 41.47 \\
\hline & & $20 \%$ & 37.83 & 38.17 & 38.53 & 38.9 & 39.3 \\
\hline
\end{tabular}


Table 2

\begin{tabular}{|c|c|c|c|c|c|c|c|}
\hline 1 & 2 & 3 & 4 & 5 & 6 & 7 & 8 \\
\hline \multirow{3}{*}{6} & \multirow{3}{*}{$\begin{array}{l}\text { The household expenses to pay for } \\
\text { accommodation, communal products } \\
\text { and service, \% }\end{array}$} & $5 \%$ & 8.98 & 9.07 & 9.16 & 9.26 & 9.37 \\
\hline & & $10 \%$ & 8.94 & 8.98 & 9.03 & 9.07 & 9.12 \\
\hline & & $20 \%$ & 8.94 & 8.98 & 9.03 & 9.07 & 9.12 \\
\hline \multirow{3}{*}{7} & \multirow{3}{*}{$\begin{array}{l}\text { unemployed persons aged } 15-70 \text { (by the } \\
\text { methodology of ILO), in } \% \text { to the } \\
\text { economically active population of the } \\
\text { relevant age group }\end{array}$} & $5 \%$ & 8.6 & 8.57 & 8.54 & 8.51 & 8.47 \\
\hline & & $10 \%$ & 8.57 & 8.51 & 8.44 & 8.37 & 8.29 \\
\hline & & $20 \%$ & 8.6 & 8.57 & 8.54 & 8.51 & 8.47 \\
\hline \multirow{3}{*}{8} & \multirow{3}{*}{$\begin{array}{l}\text { unemployed persons of the working age } \\
\text { (by the methodology of ILO), thousand } \\
\text { persons, in \% to the economically active } \\
\text { population of the relevant age group }\end{array}$} & $5 \%$ & 9.61 & 9.6 & 9.59 & 9.58 & 9.57 \\
\hline & & $10 \%$ & 9.6 & 9.58 & 9.56 & 9.54 & 9.51 \\
\hline & & $20 \%$ & 9.61 & 9.6 & 9.59 & 9.58 & 9.57 \\
\hline \multirow{3}{*}{9} & \multirow{3}{*}{$\begin{array}{l}\text { the coefficient of the workers' total } \\
\text { turnover }\end{array}$} & $5 \%$ & 53.23 & 53.25 & 3.27 & 53.29 & 53,31 \\
\hline & & $10 \%$ & 53.25 & 53.28 & 53.33 & 53.37 & 53.42 \\
\hline & & $20 \%$ & 53.23 & 53.25 & 53.27 & 53.29 & 53.31 \\
\hline \multirow{3}{*}{$\begin{array}{l}1 \\
0\end{array}$} & \multirow{3}{*}{$\begin{array}{l}\text { the total area of the housing stock, } \mathrm{mln} \\
\mathrm{m}^{2}\end{array}$} & $5 \%$ & 1002.1 & 999.99 & 997.66 & 995.08 & 992.28 \\
\hline & & $10 \%$ & 1003.1 & 1002.1 & 1001.0 & 999.88 & 998.71 \\
\hline & & $20 \%$ & 1003.1 & 1002.1 & 1001.0 & 999.88 & 998.71 \\
\hline \multirow{3}{*}{1} & \multirow{3}{*}{$\begin{array}{l}\text { specific weight of the total area of } \\
\text { housing stock, equipped with water } \\
\text { supply, } \%\end{array}$} & $5 \%$ & 62.8 & 63.67 & 64.62 & 65.67 & 66.82 \\
\hline & & $10 \%$ & 62.41 & 62.82 & 63.26 & 63.71 & 64.19 \\
\hline & & $20 \%$ & 62.41 & 62.82 & 63.26 & 63.71 & 64.19 \\
\hline \multirow{3}{*}{$\begin{array}{l}1 \\
2\end{array}$} & \multirow{3}{*}{$\begin{array}{l}\text { specific weight of the total area of } \\
\text { housing stock, equipped with hot water } \\
\text { supply, } \%\end{array}$} & $5 \%$ & 48.08 & 48.56 & 49.07 & 49.6 & 50.16 \\
\hline & & $10 \%$ & 48.54 & 49.55 & 50.66 & 51.89 & 53.24 \\
\hline & & $20 \%$ & 48.08 & 48.56 & 49.07 & 49.6 & 50.16 \\
\hline \multirow{3}{*}{1} & \multirow{3}{*}{$\begin{array}{l}\text { the consumer price index in the health } \\
\text { protection sector }\end{array}$} & $5 \%$ & 127.01 & 129.32 & 131.08 & 133.25 & 135.02 \\
\hline & & $10 \%$ & 126.48 & 127.33 & 128.21 & 129.14 & 130.12 \\
\hline & & $20 \%$ & 126.48 & 127.33 & 128.21 & 129.14 & 130.12 \\
\hline \multirow{3}{*}{1} & \multirow{3}{*}{ the consumer price index in education } & $5 \%$ & 109 & 109 & 109 & 108 & 108 \\
\hline & & $10 \%$ & 110.1 & 110 & 109.8 & 109.7 & 109.5 \\
\hline & & $20 \%$ & 110.14 & 109.99 & 109.84 & 109.67 & 109.5 \\
\hline \multirow{3}{*}{$\begin{array}{l}1 \\
5\end{array}$} & \multirow{3}{*}{$\begin{array}{l}\text { the consumer price index in the } \\
\text { recreation and culture field }\end{array}$} & $5 \%$ & 126 & 128 & 130 & 133 & 136 \\
\hline & & $10 \%$ & 125.25 & 126.29 & 127.37 & 128.51 & 129.71 \\
\hline & & $20 \%$ & 125.25 & 126.29 & 127.37 & 128.51 & 129.71 \\
\hline
\end{tabular}

Sources: calculated by authors

Scenario 1 (optimistic). It considers the annual growth of the State and local budgets social costs of Ukraine by $10 \%$ in comparison with the previous year during 2016-2020. The results of the computer imitative modelling show that the annual growth of social expenditure by $10 \%$ leads to a small reduction of households' sizes; households' expenditure on accommodation, communal products and services; the share of the unemployed persons aged 15-70 years and a share of the unemployed persons of the working age. Therefore, the share of households with children under 18 years old and the consumer price index in education will be decreased with the great simultaneous reduction of households' expenditure on food products (foodstuff and soft drinks) and the total area of the housing stock. Providing the scenario 1 , it is predicted to increase the households share without children; households expenditure share on nonfood products and service; specific weight of the total area of housing stock, equipped with water supply; specific weight of the total area of housing stock, equipped with hot water supply; consumer price index in the health protection sector and consumer price index in the recreation and culture sectors.

Scenario 2 (less optimistic). Scenario considers the annual growth of social expenditure by $5 \%$ in 
relation to the previous one during 2016-2020. The results of the computer imitative modelling show that the annual increase of the social expenditure by $5 \%$ will cause a slight decrease of households' sizes; the share of households with children up to 18 years old; the share of unemployed persons aged 15-70 years old. Therefore, one can observe some reduction of household expenditure on food products (foodstuff and soft drinks), consumer prices index in the education sector and the total area of the housing stock. Provided the scenario 2 , one can predict the increase of all other indicators by criteria.

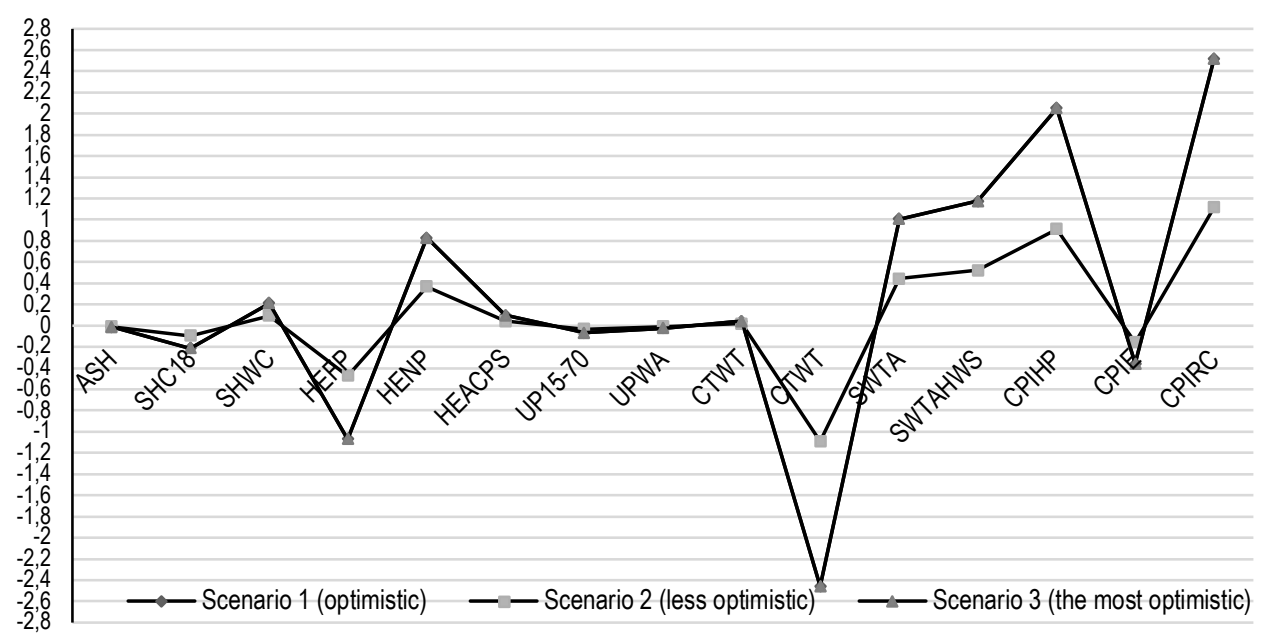

Figure 2 - Predicted results regarding the average change of the target indicators in the optimistic scenarios implementation of the social costs increase from the State and local budgets of Ukraine

\section{Sources: formed by authors}

Scenario 3 (the most optimistic). The scenario considers the annual increase of the social expenditure by $20 \%$ in relation to the previous year during $2016-2020$. The results of the imitative computer modelling show that annual increase of the social expenditure by $20 \%$, despite the previous scenario, will cause the slight decrease of households' sizes; the share of the unemployed people aged 15-70 years and the share of unemployed people of working age. At the same time, there will be the reduction of the households with children up to 18 years; households' expenditure on food products (foodstuff and soft drinks), consumer price index in education and the total area of housing stock. Provided the scenario 3 , one can predict the increase of all other indicators by criteria.

Having analysed the described scenarios, let us notice that scenario 1 (social expenditure increase by $10 \%$ ) and scenario 3 (social expenditure increase by $20 \%$ ) are almost the same based on the results. It enables to make a preliminary conclusion that $10 \%$ is an optimal marginal norm of the annual social expenditure growth rates from the state and local budgets. The next stage of our study is to model the pessimistic scenarios regarding the social expenditure impact on the citizens' life quality by the proposed criteria. Scenario 4 (the most pessimistic) considers the decrease of the State and local budget costs of Ukraine annually by $20 \%$ during 2016-2020; scenario 5 (moderately pessimistic) considers the decrease of the State and local budget costs of Ukraine annually by 10\% during 2016-2020; scenario 6 (pessimistic) considers decrease of social expenditure of the state and local budgets annually by $5 \%$ during 2016-2020.

The results of computer imitative modelling show that annual decrease of the State and local budget 
costs of Ukraine by $20 \%$ will lead to the slight reduction of household expenditure on accommodation, communal goods and service and the coefficient of the workers' total turnover (table 3).

Table 3 - Predicted impact values of the State and local budget costs of Ukraine on the citizens' life quality

\begin{tabular}{|c|c|c|c|c|c|c|c|}
\hline & Indicators of citizens' life quality & $\begin{array}{l}\text { Rates of } \\
\text { the } \\
\text { expendit } \\
\text { ure } \\
\text { growth }\end{array}$ & 2016 & 2017 & 2018 & 2019 & 2020 \\
\hline 1 & 2 & 3 & 4 & 5 & 6 & 7 & 8 \\
\hline \multirow{3}{*}{1} & \multirow{3}{*}{$\begin{array}{l}\text { The average size of the household, } \\
\text { persons }\end{array}$} & $-5 \%$ & 2.58 & 2.58 & 2.58 & 2.59 & 2.59 \\
\hline & & $-10 \%$ & 2.58 & 2.59 & 2.60 & 2.60 & 2.61 \\
\hline & & $-20 \%$ & 2.58 & 2.59 & 2.60 & 2.60 & 2.61 \\
\hline \multirow{3}{*}{2} & \multirow{3}{*}{$\begin{array}{l}\text { The share of households with children } \\
\text { up to } 18 \text { years old, } \%\end{array}$} & $-5 \%$ & 37.88 & 37.96 & 38.03 & 38.11 & 38.17 \\
\hline & & $-10 \%$ & 37.96 & 38.11 & 38.25 & 38.37 & 38.48 \\
\hline & & $-20 \%$ & 37.96 & 38.11 & 38.25 & 38.37 & 38.48 \\
\hline \multirow{3}{*}{3} & \multirow{3}{*}{$\begin{array}{l}\text { The share of households without } \\
\text { children, } \%\end{array}$} & $-5 \%$ & 62.12 & 62.04 & 61.97 & 61.89 & 61.83 \\
\hline & & $-10 \%$ & 62.04 & 61.89 & 61.75 & 61.63 & 61.52 \\
\hline & & $-20 \%$ & 62.04 & 61.89 & 61.75 & 61.63 & 61.52 \\
\hline \multirow{3}{*}{4} & \multirow{3}{*}{$\begin{array}{l}\text { The household expenditure on food } \\
\text { products (foodstuff and soft drinks)), } \%\end{array}$} & $-5 \%$ & 50.73 & 51.13 & 51.51 & 51.87 & 52.21 \\
\hline & & $-10 \%$ & 51.15 & 51.91 & 52.58 & 53.20 & 53.74 \\
\hline & & $-20 \%$ & 51.15 & 51.91 & 52.58 & 53.20 & 53.74 \\
\hline \multirow{3}{*}{5} & \multirow{3}{*}{$\begin{array}{l}\text { The household expenditure on non-food } \\
\text { products and service, \% }\end{array}$} & $-5 \%$ & 37.18 & 36.87 & 36.58 & 36.30 & 36.03 \\
\hline & & $-10 \%$ & 36.85 & 36.27 & 35.74 & 35.27 & 34.84 \\
\hline & & $-20 \%$ & 36.85 & 36.27 & 35.74 & 35.27 & 34.84 \\
\hline \multirow{3}{*}{6} & \multirow{3}{*}{$\begin{array}{l}\text { The household expenditure to pay for } \\
\text { accommodation, communal products } \\
\text { and service, } \%\end{array}$} & $-5 \%$ & 8.87 & 8.83 & 8.79 & 8.76 & 8.73 \\
\hline & & $-10 \%$ & 8.83 & 8.76 & 8.69 & 8.64 & 8.59 \\
\hline & & $-20 \%$ & 8.83 & 8.76 & 8.70 & 8.64 & 8.59 \\
\hline \multirow{3}{*}{7} & \multirow{3}{*}{$\begin{array}{l}\text { unemployed persons aged } 15-70 \text { (by the } \\
\text { methodology of } I O L \text { ), in } \% \text { to the } \\
\text { economically active population of the } \\
\text { relevant age group }\end{array}$} & $-5 \%$ & 8.65 & 8.68 & 8.70 & 8.72 & 8.75 \\
\hline & & $-10 \%$ & 8.68 & 8.73 & 8.77 & 8.81 & 8.84 \\
\hline & & $-20 \%$ & 8.68 & 8.73 & 8.77 & 8.81 & 8.84 \\
\hline \multirow{3}{*}{8} & \multirow{3}{*}{$\begin{array}{l}\text { unemployed persons of the working age } \\
\text { (by the methodology of } \mathrm{IOL} \text { ), thousand } \\
\text { persons, in \% to the economically active } \\
\text { population of the relevant age group }\end{array}$} & $-5 \%$ & 9.63 & 9.64 & 9.64 & 9.65 & 9.66 \\
\hline & & $-10 \%$ & 9.64 & 9.65 & 9.67 & 9.68 & 9.69 \\
\hline & & $-20 \%$ & 9.64 & 9.65 & 9.67 & 9.68 & 9.69 \\
\hline \multirow{3}{*}{9} & \multirow{3}{*}{$\begin{array}{l}\text { the coefficient of the workers' total } \\
\text { turnover }\end{array}$} & $-5 \%$ & 53.20 & 53.18 & 53.17 & 53.15 & 53.14 \\
\hline & & $-10 \%$ & 53.18 & 53.15 & 53.12 & 53.10 & 53.08 \\
\hline & & $-20 \%$ & 53.18 & 53.15 & 53.12 & 53.10 & 53.08 \\
\hline \multirow{3}{*}{10} & \multirow{3}{*}{$\begin{array}{l}\text { the total area of the housing stock, } \\
\mathrm{mln} \mathrm{m}^{2}\end{array}$} & $-5 \%$ & 1005.0 & 1006.0 & 1006.8 & 1007.6 & 1008.4 \\
\hline & & $-10 \%$ & 1006.0 & 1008.0 & 1009.3 & 1010.6 & 1011.9 \\
\hline & & $-20 \%$ & 1006.0 & 1008.0 & 1009.3 & 1010.6 & 1011.9 \\
\hline \multirow{3}{*}{11} & \multirow{3}{*}{$\begin{array}{l}\text { specific weight of the total area of } \\
\text { housing stock, equipped with water } \\
\text { supply, } \%\end{array}$} & $-5 \%$ & 61.62 & 61.25 & 60.89 & 60.55 & 60.23 \\
\hline & & $-10 \%$ & 61.23 & 60.52 & 59.88 & 59.30 & 58.79 \\
\hline & & $-20 \%$ & 61.23 & 60.52 & 59.88 & 59.31 & 58.79 \\
\hline \multirow{3}{*}{12} & \multirow{3}{*}{$\begin{array}{l}\text { specific weight of the total area of } \\
\text { housing stock, equipped with hot water } \\
\text { supply, } \%\end{array}$} & $-5 \%$ & 47.15 & 46.72 & 46.30 & 45.91 & 45.53 \\
\hline & & $-10 \%$ & 46.69 & 45.86 & 45.12 & 44.45 & 43.84 \\
\hline & & $-20 \%$ & 46.69 & 45.87 & 45.12 & 44.45 & 43.84 \\
\hline
\end{tabular}




\begin{tabular}{|c|c|c|c|c|c|c|c|}
\hline & & & & & & & \\
\hline 1 & 2 & 3 & 4 & 5 & 6 & 7 & 8 \\
\hline \multirow{3}{*}{13} & \multirow{3}{*}{$\begin{array}{l}\text { the consumer price index in the health } \\
\text { protection sector }\end{array}$} & $-5 \%$ & 124.00 & 124.00 & 123.00 & 122.70 & 122.04 \\
\hline & & $-10 \%$ & 124.07 & 122.62 & 121.32 & 120.15 & 119.09 \\
\hline & & $-20 \%$ & 124.00 & 122.00 & 121.00 & 120.00 & 119.00 \\
\hline \multirow{3}{*}{14} & \multirow{3}{*}{ the consumer price index in education } & $-5 \%$ & 110.40 & 110.50 & 110.60 & 110.70 & 110.90 \\
\hline & & $-10 \%$ & 110.56 & 110.81 & 111.04 & 111.24 & 111.43 \\
\hline & & $-20 \%$ & 110.00 & 110.00 & $\begin{array}{c}111, .0 \\
0\end{array}$ & 111.00 & 111.00 \\
\hline \multirow{3}{*}{15} & \multirow{3}{*}{$\begin{array}{l}\text { the consumer price index in the } \\
\text { recreation and culture field }\end{array}$} & $-5 \%$ & 123.20 & 122.30 & 121.40 & 120.60 & 119.80 \\
\hline & & $-10 \%$ & 122.00 & 120.00 & 118.00 & 117.00 & 116.00 \\
\hline & & $-20 \%$ & 122.00 & 120.00 & 118.00 & 117.00 & 116.90 \\
\hline
\end{tabular}

Sources: calculated by authors

According to scenario 4, there will be a moderate decrease in households share without children; household expenditure on non-food products and service; specific weight of the housing stock total area, equipped with water supply; specific weight of the housing stock total area, equipped with hot water supply; consumer price index in the health protection sector and consumer price index in the recreation and culture sector. Provided the scenario 4, one predicts the moderate increase of household's expenditure on food products (food and soft drinks).

Scenario 5 (moderately pessimistic) enables to make sure that if the State and local budget costs of Ukraine will be annually decreased by $10 \%$, then one may expect a small reduction of the following indicators: share of households with children up to 18 years old; households expenditure on non-food products and service; households expenditure on accommodation, communal products and service; the coefficient of the workers' total turnover; specific weight of the housing stock total area, equipped with water supply.

According to scenario 5 , the following indicators will be reduced: consumer price index in the recreation and culture sector and consumer price index in the health protection sector. Provided the scenario 5 , unemployment indicators will not essentially grow, and all other resulting indicators will slowly grow.

Scenario 6 (pessimistic) justifies that if the State and local budget costs of Ukraine are reduced by $5 \%$, the following indicators will slightly decrease: the share of households without children, the coefficient of the workers' total turnover and household's expenditure on accommodation communal products and service. It distinguishes this scenario among other previous pessimistic scenarios 4 and 5 . Therefore, the consumer price index in the recreation and culture sector and consumer price index in the health protection sector will decrease.

Scenario 6 justifies that if the State and local budget costs of Ukraine are annually decreased by $5 \%$, unemployment indicators will not be greatly changed, and all other resulting indicators will slowly grow.

In general, the carried-out analysis of the pessimistic scenarios of the social expenditure impact on citizens' life quality by the proposed criteria enables to confirm that $10 \%$ is the maximum permissible reduction of the State and local budget costs of Ukraine. 


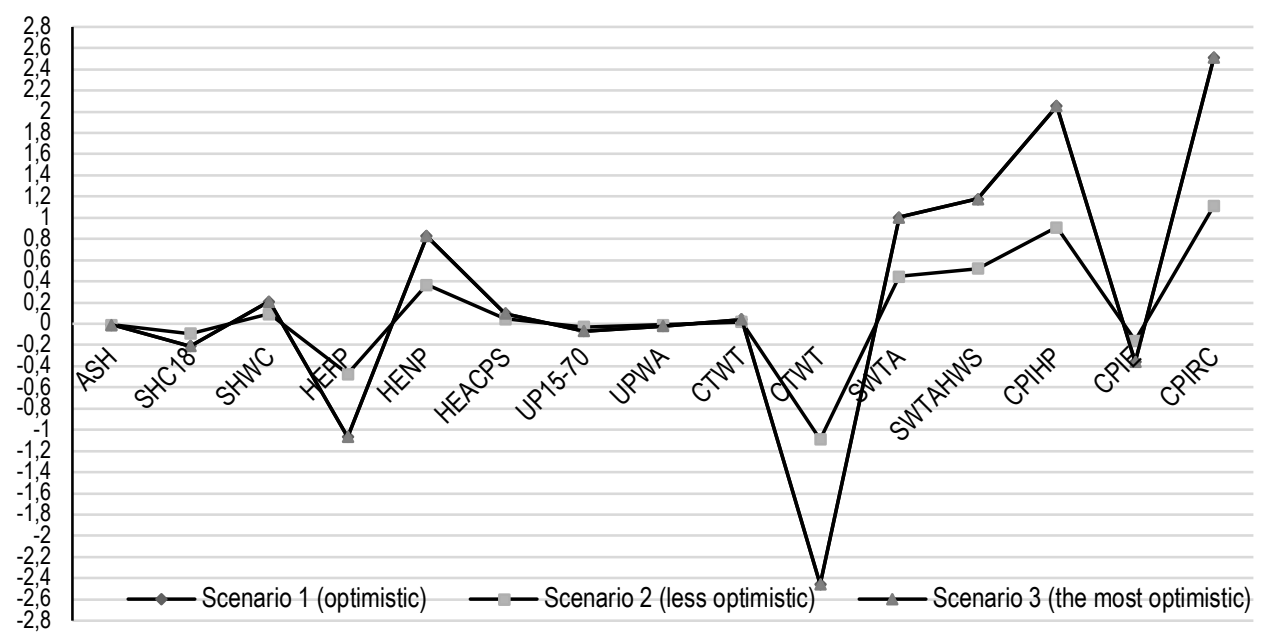

Figure 3 - Expected results regarding the average change of the target indicators in the implementation of pessimistic scenarios of the State and local budget costs of Ukraine

\section{Sources: formed by authors}

Thus, the proposed model and performed model experiments enable to find marginal conditions to manage the State and local budget costs of Ukraine, which are oriented to human development, and to conclude, that $10 \%$ is the optimal marginal norm of the relevant expenditure annual rates over the five years. Therefore, the admissibility of the annual financing decrease more than $10 \%$ of the financing during the previous years, is established. Taking into account the above, the financial regulation system of human development has to be improved considering the social development priorities, economic cyclicity, financial system transformations and the leading experience of countries with the developed transformational economy. The peculiarities of countries with the socially oriented economy are defined both by the amount of expenditure for social sector maintenance and development and by their significant impact on the citizens' welfare. The human development index, calculated on the basis of citizens' material situation and social and demographic indicators, justifies the efficiency of the fiscal policy measures. Traditionally, countries with "Scandinavian" and west-European model of the economic and social development are in the category with the highest degree of human development. At the same time, despite the great amounts of the state financial provision of social sector branches, diversification of the financing sources regarding projects and programs in the educational and medical sector in these countries is greatly increased the insurance medicine and accumulative level of the pension system are being developed. Given the recession, the state's role to provide the financial market stabilization grows that is a necessary condition for the functioning of the non-state pension maintenance and the obligatory and voluntary insurance programs.

Conclusions and directions of further studies. The financial provision of the human development programs, to a large extent, is carried out using the funds of the state and local budgets, state specialized funds of the social insurance. The native budget policy is oriented to fulfil tasks of the country's social development, evidenced by the structure of the costs part in the state and local budgets in terms of the functional classification. The budget costs are redistributed between constituents of the budget system through the inter-budgetary transfers, including subventions to implement the state programs of social protection, educational and medical subvention, caused by the necessity to fulfil the set tasks in this sector 
by the public authorities and local self-government taking into account the principles of subsidiarity, clearness and effectiveness. In order to increase the economic transformations efficiency, it is reasonable to improve the financial institutions' activity, which fasten the productive forces reproduction rates. The priority directions of the state financial policy for human development have to be the formation of state social programs hierarchic system, deployment of the institutional constituent for education, science and health protection financing, efficiency increase to use the program-target method in the budgetary process, increase of cooperation efficiency between state budget and local budgets, improvement of the pension maintenance system. It is important to fix the role of the human development financial constituent to provide economic growth processes. It is reasonable to develop and to implement human development programs of the territorial communities, combining the budgetary financing mechanism, finance and credit institutions' funds and institutional investors. Taking into account the above, territorial communities have to receive powers to combine these sources in order to implement tasks and obligations in the human development sector. This mechanism will enable the local self-government to increase the quality of public service and to strengthen their financial independence. The financial resources, which are enough for the financing of territorial communities' human development actions, have to be assigned with the formation of the effective system of efficiency indicators monitoring to use the proper funds. The given directions implementation will help to increase the level of the functional adaptivity of the native system for human development state financial regulation. Under modern conditions of the social and economic relations transformations, it is reasonable to improve methodological principles to form budget programs, to strengthen the level of their coordination with state target programs, a great deal of which is oriented to human development. Priority tasks of the state fiscal policy are to increase the quality to plan indicative values of the resulting indicators in the above programs, that requires further improvement of the financial and economic prediction system. It is important to form the strategy regarding the financial support of social sector branches, which has to be developed according to the conceptual tasks to increase the qualitative human development and is adapted to the macroeconomic dynamics changes, institutional transformations of the state finance system and the globalization factors impact.

Funding. The article was executed in the framework of state budget scientific research work №0117U003935 "Development of scientific and methodological foundations and practical tools of financial policy of sustainable development of united territorial communities".

\section{References}

Bobukh I. (2014). Tendenciyi parametriv formuvannya lyuds`kogo potencialu Ukrayiny` u mizhnarodnomu konteksti [Trends in the parameters of formation of human potential of Ukraine in the international context]. Aktual'ni problemy' ekonomiky'-Actual problems of the economy, 3, 334-341. [in Ukrainian].

Bogolib, T. (2015). Byudzhetna polity ka yak instrument makroekonomichnoyi stabil'nosti [Budget policy as an instrument of macroeconomic stability]. Ekonomichny'j chasopy's XXI - Economic Journal XXI, 3-4(1), 84-87. [in Ukrainian].

Campbell, Y. John. (2006). Household Finance. Retrieved from http://campbell_afapresidentialaddress_jf2006.pdf/.

Chugunov, I. \& Kozarezenko, L. (2017). Derzhavne finansove reguliuvannia rozvytku liudskogo potencialu [State financial regulation of human potential development]. Visnyk KNTEU - Bulletin of KNTEU, 3, 116-132 [in Ukrainian].

Geets, V. (2009). Suspil'stvo, derzhava, ekonomika: fenomenologiya vzayemodiyi ta rozvy'tku [Society, state, economics: phenomenology of interaction and development]. Kyiv: In-t ekon. ta prognozuv. NAN Ukrayiny'. [in Ukrainian].

Hicks, N. (1980). Economic Growth and Human Resources. World Bank Staff Working Paper. no. 408. Retrieved from http://documents.worldbank.org/curated/en/178991468739490287/Economic-growth-and-human-resources

Kolesov, V. (Eds.). (2008). Chelovecheskoe razvitie: novoe izmerenie social'no-jekonomicheskogo progressa [Human development: a new dimension of socio-economic progress]. Moscow: Prava cheloveka. [in Russian].

Kozarezenko, L. (2016). Finansova polityka rozvytku liudskogo potencialu [Financial Policy for the Development of Human Potential]. Kyiv: Center for Educational Literature [in Ukrainian]

Lucas, R. (1988). On the Mechanics of Economic Development. Journal of Monetary Economics, 22, 3-42. 
Machlup, F. (1984). The Economics of Information and Human Capital. Princeton, N. J.: Princeton University Press.

Mankiw, G., Romer D. \& Weil D. (1992). A Contribution to the Empirics of Economic Growth. Quarterly Journal of Economics, $107,407-438$.

Mehrotra, S. \& Jolly, R. (1997). Development with a Human Face: Experiences in Social Achievement and Economic Growth. Oxford: Oxford University Press

Murphy, K., Shleifer, A. \& Vishny, R. (1991). The Allocation of Talent: Implications for Growth. Quarterly Journal of Economics, 106, 503-530.

Petrushenko, Y. (2014). Analysis of the Stability of Local Budgets in the Context of Financial Policy of the Territorial Communities Development. European Journal of Economic Studies, 3, 170-176. [in Ukrainian].

Petrushenko, Yu. (2013). Finansove zabezpechennia socialno-ekonomichnogo rozvytku terytorialnykh gromad: konceptualni zasady ta praktychnyi instrumentariy [Financial support of socio-economic development of territorial communities: conceptual foundations and practical tools]. Sumy: University Book [in Ukrainian].

Popov, V. (2011). Strategii jekonomicheskogo razvitja [Economic Development Strategies]. Moscow: Vysshaja shkola jekonomiki [in Russian].

Pospelova, T. (2011). Mexanizmy' derzhavnogo upravlinnya lyuds'ky'm rozvy'tkom v Ukrayini [Mechanisms of public administration of human development in Ukraine]. Donecz'k: Noulidzh [in Ukrainian].

Sen, A. (1989). Development as Capability Expansion. Journal of Development Planning, 19, 41-58.

Stefanyshyn, O. (2006). Lyuds'ky'j potencial ekonomiky' Ukrayiny' [The human potential of the Ukrainian economy]. Lviv: $V y^{\prime}$ davny'chy'j centr LNU im. Ivana Franka [in Ukrainian].

Stiglitz, J. (2011). Krutoe pike: Amerika i novyj jekonomicheskij porjadok posle global'nogo krizisa Steep dive: America and the new economic order after the global crisis]. Moscow: Exmo. [in Russian].

Taragul, L. (Eds.). (2012). Byudzhetna pidtry 'mka ta podatkove sty 'mulyuvannya nacional'noyi ekonomiky 'Ukrayiny' [Budget support and tax incentives for the national economy of Ukraine]. Irpin': Feniks [in Ukrainian].

Tulai, O. (2016). Derzhavni finansy i staliy liudskiy rozvytok: konceptualni dominanty ta dialektychna yednist [Public Finances and Sustainable Human Development: Conceptual Dominances and Dialectic Unity]. Ternopil: TNEU [in Ukrainian].

Tulai, O. (2017). Conceptual framework for state budget policy formation. Modern tendencies of fiscal policy in European economic space, pp. 44-50. Ternopil: TNEU [in Ukrainian].

Wheeler, D. (1980). Human Resource Development and Economic Growth in Developing Countries: A Simultaneous Model. World Bank Staff Working Paper. no. 407. 129 p.

Л. В. Козарезенко, д.е.н., професор, Київський національний торговельно-економічний університет (Україна);

ю. М. Петрушенко, д.е.н., професор, Сумський державний університет (Україна);

O. I. Тулай, д.е.н., професор, Тернопільський національний економічний університет (Україна).

Інновації в управлінні публічними фінансами сталого людського розвитку

Доведено, що особливості країн з соціально-орієнтованою економікою визначаються як достатнім обсягом видатків на утримання та розвиток соціальної сфери, так і ї суттєвим впливом на добробут громадян, про що свідчить індекс людського розвитку, який розраховується на основі сукупності показників матеріального становища населення та соціальнодемографічних індикаторів. У категорії з найвищим рівнем людського розвитку традиційно перебувають країни з скандинавською та західноєвропейською моделями соціально-економічного розвитку. Виявлено, що, незважаючи на значні обсяги державного фінансового забезпечення галузей соціальної сфери в даних країнах посилюється диверсифікація джерел фонансування проектів і програм у освітній та медичній галузі, відбувається розвиток страхової медицини та накопичувального рівня пенсійної системи. Доведено доцільність використання цілісної архітектоніки фінансового регулювання економіки, подальше удосконалення положень щодо інституційних механізмів фінансового забезпечення сталого людського розвитку, які цілеспрямовано застосовуються державними інститутами. За допомогою запропонованої моделі та розрахунків доведено граничні умови управління соціальними видатками Державного та місцевих бюджетів України, що спрямовуються на людський розвиток. Обгрунтовано, що 10\% є оптимальною граничною нормою щорічних темпів зростання відповідних видатків на п'ятирічному зрізі. При цьому встановлено недопустимість щорічного зменшення обсягів фінансування більше, ніж на 10\% від обсягів фінансування попередніх років. Наголошено, що вдосконалення системи фінансового регулювання сталого людського розвитку має здійснюватися з урахуванням пріоритетів суспільного розвитку, економічної циклічності, перетворень фінансової системи та провідного досвіду країн з розвинутою та трансформаційною економікою.

Ключові слова: фінансова політика, бюджетна політика, фінансове забезпечення, інновації, видатки бюджету, сталий людський розвиток.

Manuscript received: 21.10.2018

(C) The author(s) 2018. This article is published with open access at Sumy State University. 